\title{
Oxigênio Suplementar e Incidência de Náuseas e Vômitos Perioperatórios no Parto Cesariano sob Anestesia Subaracnoidea *
}

\section{Supplemental Oxygen and the Incidence of Perioperative Nausea and Vomiting in Cesarean Sections under Subarachnoid Block*}

\author{
Fernanda Salomão Turazzi Pécora ${ }^{1}$, Luiz Marcelo Sá Malbouisson, TSA ${ }^{2}$, Marcelo Luis Abramides Torres, TSA ${ }^{3}$
}

\section{RESUMO}

Pécora FST, Malbouisson LMS, Torres MLA - Oxigênio Suplementar e Incidência de Náuseas e Vômitos Perioperatórios no Parto Cesariano sob Anestesia Subaracnoidea.

JUSTIFICATIVA E OBJETIVOS: Oxigênio suplementar pode reduzir a incidência de náuseas e vômitos pós-operatórios em pacientes submetidos à anestesia geral. O objetivo deste estudo foi testar a eficácia do oxigênio suplementar durante a cesariana eletiva sob anestesia subaracnoidea em diminuir a incidência de náuseas e vômitos perioperatórios.

MÉTODO: Após indução de anestesia subaracnoidea padronizada, noventa e quatro parturientes submetidas ao parto operatório foram distribuídas de forma aleatória para receberem, através de cateter nasal tipo óculos, 4 L.min ${ }^{-1}$ de oxigênio (Grupo O) ou ar comprimido (Grupo S) até o final do procedimento. As pacientes foram inquiridas acerca da ocorrência de náuseas e vômitos durante a operação e nas primeiras seis e 24 horas de pós-parto.

RESULTADOS: Os dois grupos mostraram-se comparáveis quanto às variáveis demográficas, perioperatórias e quanto aos dados do recém-nascido. No Grupo $O$, a incidência de náusea durante a operação nas primeiras 6 horas de pós-operatório e entre 6 e 24 horas de pós-operatório foi de 35\%, 20\% e 13\%, respectivamente, enquanto no Grupo S foi de 35\%, 30\% e 19\%, respectivamente. A incidência de vômito no Grupo O foi de 9\%, $11 \%$ e $6 \%$ nos períodos correspondentes e no Grupo S 21\%, 7\% e 7\%, respectivamente. Essas diferenças não foram significativas.

CONCLUSÕES: Na população estudada, a oxigenoterapia suplementar desde a indução da anestesia até o término da operação

* Recebido do Hospital das Clínicas da Faculdade de Medicina da Universidade de São Paulo (HC-FMUSP), São Paulo, SP.

1. Médica Assistente do Serviço de Anestesia do Instituto da Criança do HCFMUSP

2. Doutor em Ciências pela USP; Médico Supervisor da UTI-Anestesia do Instituto Central do HC-FMUSP.

3. Professor Doutor em Medicina pela Disciplina de Anestesiologia da FMUSP; Médico Supervisor do Serviço de Anestesia do Instituto da Criança do HCFMUSP.

Apresentado (Submitted) em 24 de janeiro de 2009

Aceito (Accepted) para publicação em 11 de junho de 2009

Endereço para correspondência (Correspondence to):

Dra. Fernanda Salomão Turazzi Pécora

R. Cel. Melo de Oliveira, 697, ap 31

Vila Pompéia

05011-040 São Paulo, SP

E-mail: fsturazzi@yahoo.com.br não reduziu a incidência de náuseas ou vômitos intraoperatórios e pós-operatórios em mulheres submetidas ao parto cesariano sob anestesia subaracnoidea.

Unitermos: CIRURGIA, Obstétrica: cesariana; COMPLICAÇÕES: náusea e vômito; TÉCNICAS ANESTÉSICAS, Regional: subaracnoidea.

\section{SUMMARY}

Pécora FST, Malbouisson LMS, Torres MLA - Supplemental Oxygen and the Incidence of Perioperative Nausea and Vomiting in Cesarean Sections Under Subarachnoid Block.

BACKGROUND AND OBJECTIVES: Supplemental oxygen can reduce the incidence of postoperative nausea and vomiting in patients under general anesthesia. The objective of the present study was to determine the efficacy of supplemental oxygen to reduce the incidence of perioperative nausea and vomiting in elective cesareans under subarachnoid block.

METHODS: After induction of standardized subarachnoid block, 94 parturients undergoing surgical delivery were randomly divided to receive 4 L. min $^{-1}$ of oxygen (Group O) or medical air (Group S) under nasal cannula throughout the procedure. Patients were questioned on the development of nausea and vomiting during the surgery and in the first six and 24 hours after the procedure.

RESULTS: Demographic and perioperative parameters, as well as the data on the newborn, were comparable in both groups. In Group $O$, the incidence of nausea during the surgery, in the first 6 hours afterwards, and between 6 and 24 hours was 35\%, 30\%, and 19\%, respectively, while in Group S, it was 35\%, 30\%, and 19\%, respectively. In Group O, the incidence of vomiting was 9\%, $11 \%$ and $6 \%$ in the corresponding periods, and in Group S, $21 \%$, $7 \%$ and $7 \%$, respectively. Those differences were not statistically significant.

CONCLUSIONS: The administration of supplemental oxygen from anesthetic induction until the end of the surgery did not reduce the incidence of intra- and postoperative nausea or vomiting in women undergoing cesarean section under subarachnoid block.

Keywords: ANESTHETIC TECHNIQUES, Regional: subarachnoid; COMPLICATIONS: nausea and vomiting; SURGERY, Obstetric: cesarean section.

\section{INTRODUÇÃO}

A combinação de pequenas doses de opioide e anestésico local na anestesia subaracnoidea tornou-se consagrada como método eficaz e seguro para anestesia intraoperatória 


\section{Supplemental Oxygen and the Incidence of Perioperative Nausea and Vomiting in Cesarean Sections under Subarachnoid Block}

\author{
Fernanda Salomão Turazzi Pécora 1; Luiz Marcelo Sá \\ Malbouisson, TSA, M.D. ${ }^{2}$; Marcelo Luis Abramides Torres, \\ TSA, M.D. ${ }^{3}$
}

\section{INTRODUCTION}

The combination of small doses of opioids and local anesthetic in subarachnoid block is considered an effective and safe method of intraoperative anesthesia and postoperative analgesia in cesarean sections ${ }^{1-5}$; however, it is associated with the development of complications such as pruritus, urinary retention, nausea, and vomiting.

Nausea and vomiting, which are very uncomfortable for parturients, are common during and after subarachnoid blocks. The incidence of nausea and vomiting related with spinal block for cesarean section ranges from 28 and $63 \%$, and it remains elevated despite the development of new antiemetic drugs ${ }^{3,6-8}$. The best preventive strategy has not been determined. Pharmacological methods are often ineffective and they are also associated with potential risks of side effects ${ }^{9}$, which deserve extra attention when dealing with parturients. Recently, studies on non-pharmacological methods that might be beneficial on preventing the development of postoperative nausea and vomiting (PONV) have gained more importance in the medical literature ${ }^{10,11}$.

Routine administration of supplemental oxygen during elective cesarean section under regional block is controversial, and it still stirs discussions in the scientific community on its efficacy and improvement of fetal well-being ${ }^{12,13}$. On the other hand, recent studies have shown evidence that supplemental oxygen is a very effective and low cost alternative in the prevention of PONV in open or laparoscopic abdominal surgeries under general anesthesia, decreasing the incidence of those events by half ${ }^{14,15}$. However, the same effect has not been demonstrated in other groups of patients ${ }^{16-21}$.

The objective of this study was to determine the efficacy of supplemental oxygen to reduce the incidence of perioperative nausea and vomiting in elective cesarean section under subarachnoid block.

\section{METHODS}

After approval by the Ethics on Research Committee of the Institution and signing of the informed consent, 94 parturients, classified P1 or P2 according to ASA criteria, ages 14 to 43 years, admitted to the Obstetric Center of the Hospital das Clínicas of the Medical School of Universidade de São Paulo for elective cesarean section were recruited for this study. Exclusion criteria were as follows: any contraindication to the anesthetic technique, parturients weighing less than $50 \mathrm{~kg}$ or more than $120 \mathrm{~kg}$, and history of diabetes mellitus or gastrointestinal disorders. Pre-anesthetic medication was not administered. The sample size was calculated to demonstrate a $50 \%$ reduction in the incidence of nausea and vomiting. To this end, it was considered the incidence of nausea and/or vomiting of $40 \%$ in Group S and $20 \%$ in Group $\mathrm{O}$, and study power of $80 \%$ for $p$ equal to 0.05 . It was determined that 90 patients were necessary (Sigmastat 3.11, Systat Inc, USA).

After arrival to the operating room, patients were monitored (cardioscope, pulse oximeter, and intermittent non-invasive blood pressure), and an 18 or $20 \mathrm{G}$ catheter $(1.2$ or $0.9 \mathrm{~mm}$ external diameter) was used for venipuncture. All patients underwent subarachnoid block. With the patient in the sitting position, the subarachnoid space was identified with the introduction of a Withacre 25 or $27 \mathrm{G}$ needle (external diameter of 0.5 or $0.4 \mathrm{~mm}$ ) in the $L_{2-3}$ or $L_{3-4}$ intevertebral space. After visualization of drops of CSF, $3.0 \mathrm{~mL}$ of $0.5 \%$ hyperbaric bupivacaine and $0.06 \mathrm{mg}$ of morphine were administered in the subarachnoid space over 60 seconds. The patient was placed in horizontal dorsal decubitus with a discrete left lateral inclination by placing a cushion under the right buttock (to minimize aortocaval compression) until satisfactory anesthesia was observed (thermal blockade at $\mathrm{T}_{6}$ or above), when the surgery was initiated. Ringer's lactate, $10 \mathrm{~mL} \cdot \mathrm{kg}^{-1}$, was administered over 20 to 30 minutes, followed by the administration of $10 \mathrm{~mL} \cdot \mathrm{kg}^{-1} \cdot \mathrm{h}^{-1}$ of the same solution during the procedure. Using sealed envelopes, patients were randomly divided into two groups: Group $O(n=50)$ received 4 L. min $^{-1}$ of oxygen via a nasal catheter until de end of the surgery, and Group $S(n=44)$ received medical air in the same manner. A fall in systolic blood pressure greater than $20 \%$ of baseline was treated with repeated doses of $0.2 \mathrm{mg}$ of metaraminol until it returned to adequate levels. Noninvasive blood pressure was recorded every 2 to 5 minutes, as well as heart rate and pulse oximetry. Additional oxygen was administered as needed to maintain pulse oximetry of at least $95 \%$.

After fetal extraction and placental detachment, $2 \mathrm{~g}$ of dypirone and $100 \mathrm{mg}$ of ketoprophen were administered intravenously, to supplement postoperative analgesia, as well as 20 units of oxytocin in the Ringer's lactate solution. Data on the newborn (Apgar on the $1^{\text {st }}$ and $5^{\text {th }}$ minutes, weight, $\mathrm{pH}$ of umbilical cord blood) and the time between anesthesia and fetal extraction were recorded. 
During and at the end of the surgery, the anesthesiologist (or anesthesiology resident) asked the patient whether she experienced nausea; if this was present, it was classified as mild, moderate, severe, or very severe. The development of vomiting, as well as the number of episodes, was also recorded. Patients were asked about their degree of satisfaction with the anesthesia, classifying it as extremely dissatisfied, somewhat dissatisfied, neutral, somewhat satisfied, and extremely satisfied. Severe/very severe episodes of nausea and vomiting were treated with the intravenous administration of an antiemetic drug. Other pertinent information, such as age, weight, height, number of pregnancies, history of postoperative nausea and vomiting and/or kinetosis, and smoking were recorded for comparison. The use of opioids for postoperative analgesia was also recorded.

The same parameters on nausea and vomiting and patient satisfaction were recorded 6 and 24 hours after delivery, during the post-anesthetic evaluation, by the author.

The results in both groups were compared using an adequate statistical method. Nominal data were described as absolute and relative frequencies, and the association among those parameters with the groups was analyzed by the Chi-square test, or Fisher Exact test when the sample size was not enough for the Chi-square test. For numerical measurements, summarized measurements (mean and standard deviation) were calculated for each group, and the non-paired Student $t$ test was used to compare means between both groups. To analyze whether patients with intraoperative nausea or vomiting were the same that developed them postoperatively, the kappa index of concordance was used. A level of $5 \%$ was considered significant.

\section{RESULTS}

One patient was excluded from Group $S$ because anesthesia had to be converted into general anesthesia. In Group O, four patients were excluded: one had prior bariatric surgery, one had received prophylactic antiemetic treatment (ondansetron) after fetal extraction, a third received an antiemetic drug (metochlopramide every 8 hours) postoperatively, and the fourth patient was excluded because the fetus was diagnosed with severe hydrops fetalis and died during the first hours of life. Therefore, 89 patients completed the study, 43 in Group $S$ and 46 in Group O.

The mean age of patients in Group $\mathrm{O}$ was 30 years, and 29 years in Group S. Mean body mass index (BMI) and mean weight were similar in both groups. The mean number of pregnancies was 2.5 in Group $\mathrm{O}$ and 2.4 in Group S, while the mean number of deliveries was 1.2 in both groups. Group $O$ had a mean gestational age of 37 weeks, and Group S 38 weeks. Seven patients in Group O and four patients in Group $\mathrm{S}$ were smokers. The prevalence of prior history of postoperative nausea and vomiting (PONV) was $8.7 \%$ in Group O, and $18.6 \%$ in Group S, while the prevalence of kinetosis in Group $\mathrm{O}$ and Group S was $15.2 \%$ and $18.6 \%$, respectively. Demo- graphic (Table I) and perioperative parameters (Table II) as well as data regarding the newborn (Table III) were similar in both groups. The number of newborns with Apgar below 8 in the $1^{\text {st }}$ minute was similar in both groups (10 in Group $\mathrm{O}$ and 7 in Group S, which was not statistically significant). On the $5^{\text {th }}$ minute only one newborn in Group $\mathrm{O}$ had an Apgar below 8 . Eight patients in each group also underwent tubal ligation. The mean maximal and minimal variation in systolic

Table I - Demographic Parameters

\begin{tabular}{lcc}
\hline Parameter & $\begin{array}{c}\text { Group O } \\
(\mathrm{n}=46)\end{array}$ & $\begin{array}{c}\text { Group S } \\
(\mathrm{n}=43)\end{array}$ \\
\hline Age (years) & $30 \pm 7$ & $29 \pm 5$ \\
Weight (kg) & $76 \pm 15$ & $76 \pm 15$ \\
Height (cm) & $161 \pm 7$ & $160 \pm 7$ \\
BMl (kg.m $\left.{ }^{-2}\right)$ & $29 \pm 5$ & $29 \pm 5$ \\
\# of Pregnancies & $2.5 \pm 1.4$ & $2.4 \pm 1.3$ \\
\# of Deliveries & $1.2 \pm 1.3$ & $1.2 \pm 1.1$ \\
Gestational Age (weeks) & $37 \pm 2$ & $38 \pm 1$ \\
ASA 1 / 2 & $15 / 31$ & $19 / 24$ \\
Smoking & $7(15.2 \%)$ & $4(9.3 \%)$ \\
History of PONV & $4(8.7 \%)$ & $8(18.6 \%)$ \\
Kinetosis & $7(15.2 \%)$ & $8(18.6 \%)$ \\
\hline
\end{tabular}

Results expressed as Mean $\pm \mathrm{SD}$ and frequency.

Table II - Perioperative Parameters

\begin{tabular}{lcc}
\hline Parameter & $\begin{array}{c}\text { Group O } \\
(\mathrm{n}=46)\end{array}$ & $\begin{array}{c}\text { Group S } \\
(\mathrm{n}=43)\end{array}$ \\
\hline Cesarean section + Tubal ligation & $8(17.4 \%)$ & $8(18.6 \%)$ \\
Maximal variation in SBP & $24 \% \pm 12$ & $21 \% \pm 11$ \\
Induction-fetal extraction time (min) & $36 \pm 12$ & $37 \pm 9$ \\
Use of opioids & & \\
$\quad$ Intraoperative & $0(0 \%)$ & $1(2.3 \%)$ \\
$\quad$ Postoperative (6h) & $16(34.8 \%)$ & $12(27.9 \%)$ \\
$\quad$ Postoperative $(24 \mathrm{~h})$ & $13(28.3 \%)$ & $13(30.2 \%)$ \\
\hline
\end{tabular}

Results expressed as Mean \pm SD and frequency.

Table III - Newborn-Related Parameters

\begin{tabular}{lcc}
\hline Parameter & $\begin{array}{c}\text { Group O } \\
(\mathrm{n}=46)\end{array}$ & $\begin{array}{c}\text { Group S } \\
(\mathrm{n}=43)\end{array}$ \\
\hline Umbilical cord pH & $7.21 \pm 0.06$ & $7.22 \pm 0.08$ \\
Weight NB $(\mathrm{g})$ & $3093 \pm 1082$ & $3127 \pm 734$ \\
\hline
\end{tabular}

Results expressed as Mean $\pm \mathrm{SD}$. 
blood pressure was $24 \%$ and $21 \%$ in Group O and Group S, respectively. The time between anesthetic induction and fetal extraction was similar in both groups. Only one patient in Group S, and none in Group O, received intravenous fentanyl $100 \mu \mathrm{g}$ to complement intraoperative analgesia. The postoperative administration of opioids to complement analgesia, $100 \mathrm{mg}$ of tramadol IV, did not differ in both groups.

The incidence of nausea and vomiting in both groups was not statistically significant. Group $\mathrm{O}$ had a $34.8 \%$ incidence of intraoperative nausea and Group S $34.9 \%$, while the incidence of vomiting was $8.7 \%$ in Group O and $20.9 \%$ in Group S. In Group $047 \%$ of the cases of intraoperative nausea were considered mild, $18 \%$ moderate, $6 \%$ severe, and $29 \%$ very severe; in Group S $27 \%$ were considered mild, $20 \%$ moderate, and $53 \%$ very severe. In the first six postoperative hours, Group O had a $19.6 \%$ (11\% mild, and $89 \%$ very severe) incidence of nausea and $10.9 \%$ of vomiting; Group $S$ had a $30.2 \%$ incidence of nausea (31\% mild, $15 \%$ moderate, $8 \%$ severe, and $46 \%$ very severe) and $7 \%$ of vomiting. Between six and 24 hours the incidence of nausea was $13 \%$ in Group $\mathrm{O}$ and $18.6 \%$ in Group S, and $6.5 \%$ and $7 \%$ incidence of vomiting, respectively, of the late episodes of nausea $17 \%$ were classified as severe and $83 \%$ very severe in Group O, and in Group S 37\% were mild, 25\% moderate, and $38 \%$ very severe. As for intraoperative vomiting three patients in Group $\mathrm{O}$ had one episode and two patients had two episodes; in Groups $S$ five patients had one episode of vomiting, three had two episodes, and one had three episodes of vomiting. In the first six postoperative hours two patients in Group $\mathrm{O}$ had one episode of vomiting and one had two episodes; in Group S two patients had one episode of vomiting and one patient had two episodes. Between 6 and 24 hours all patients in Group $O$ that vomited did it only once, and in Group $S$ two patients had one episode and one had three episodes. Those results are shown in table IV. Continuous intraoperative supplemental oxygen did not decrease the incidence of events 6 and 24 hours after the procedure.

Table IV shows the use of rescue antiemetic medication, and table $\mathrm{V}$ patient satisfaction with anesthesia. Intravenous metochlopramide $(10 \mathrm{mg}$ ) was administered to nine patients during the surgery; two patients in Group $\mathrm{O}$ also received intravenous ondansetron ( $4 \mathrm{mg}$ ) and, in Group S one patient also received ondansetron $(4 \mathrm{mg})$ and one patient received intravenous dimenidrate $(30 \mathrm{mg})$. In the first six postoperative hours, intravenous metochlopramide was administered to ten patients; however, one patient in Group $S$ also received intravenous ondansetron ( $4 \mathrm{mg}$ ). Between 6 and 24 hours six patients required antiemetic medication and intravenous metochlopramide (10 mg) was administered to all of them, but one patient in Group $\mathrm{O}$ also received intravenous ondansetron.

Excluding mild events, the incidence of moderate, severe, and very severe nausea and vomiting was not statistically different in both groups (Table VI).
Table IV - Perioperative Nausea, Vomiting, and the use of Antiemetics

\begin{tabular}{lccc}
\hline & $\begin{array}{c}\text { Group O } \\
(\mathrm{n}=46)\end{array}$ & $\begin{array}{c}\text { Group S } \\
(\mathrm{n}=43)\end{array}$ & $p$ \\
\hline Intraoperative & & & \\
$\quad$ Nausea & $16(34.8 \%)$ & $15(34.9 \%)$ & 0.992 \\
Vomiting & $4(8.7 \%)$ & $9(20.9 \%)$ & 0.102 \\
Antiemetics & $2(4.3 \%)$ & $7(16.3 \%)$ & 0.083 \\
Postoperative 6h & & & \\
Nausea & $9(19.6 \%)$ & $13(30.2 \%)$ & 0.244 \\
Vomiting & $5(10.9 \%)$ & $3(7 \%)$ & 0.715 \\
Antiemetics & $5(10.9 \%)$ & $5(11.6 \%)$ & $>0.999$ \\
Postoperative 6- 24h & & & \\
Nausea & $6(13 \%)$ & $8(18.6 \%)$ & 0.471 \\
Vomiting & $3(6.5 \%)$ & $3(7 \%)$ & $>0.999$ \\
Antiemetics & $4(8.7 \%)$ & $2(4.7 \%)$ & 0.678 \\
\hline
\end{tabular}

Table V - Patient Satisfaction with the Anesthetic Technique

\begin{tabular}{lcc}
\hline & $\begin{array}{c}\text { Group O } \\
(\mathrm{n}=46)\end{array}$ & $\begin{array}{l}\text { Group S } \\
(\mathrm{n}=43)\end{array}$ \\
\hline IPO & $44(95.7 \%)$ & $43(100 \%)$ \\
6h postoperative & $44(95.7 \%)$ & $43(100 \%)$ \\
24h postoperative & $44(95.7 \%)$ & $43(100 \%)$ \\
\hline
\end{tabular}

IPO - immediate postoperative period

Table VI - Perioperative Incidence of Non-Mild Events

\begin{tabular}{lcc}
\hline Nausea or vomiting & $\begin{array}{c}\text { Group O } \\
(\mathrm{n}=46)\end{array}$ & $\begin{array}{c}\text { Group S } \\
(\mathrm{n}=43)\end{array}$ \\
\hline Intraoperative & $8(17.4 \%)$ & $12(27.9 \%)$ \\
6h postoperative & $8(17.4 \%)$ & $9(20.9 \%)$ \\
6-24h postoperative & $6(13 \%)$ & $5(11.6 \%)$ \\
\hline
\end{tabular}

The role of several parameters as risk factors for nausea and vomiting in this population in the three periods was also analyzed. Table VII shows those results. A history of kinetosis $(p=0.004)$, adding tubal ligation to the surgical procedure $(p=0.043)$, and lower weight $(p=0.019)$ and BMI $(p=0.022)$ were identified as intraoperative risk factors. In the first six postoperative hours, a history of PONV was the only risk factor statistically significant. Between 6 and 24 hours postprocedure, an association with the factors analyzed was not observed. 
Table VII - Risk Factors for Perioperative Nausea and Vomiting

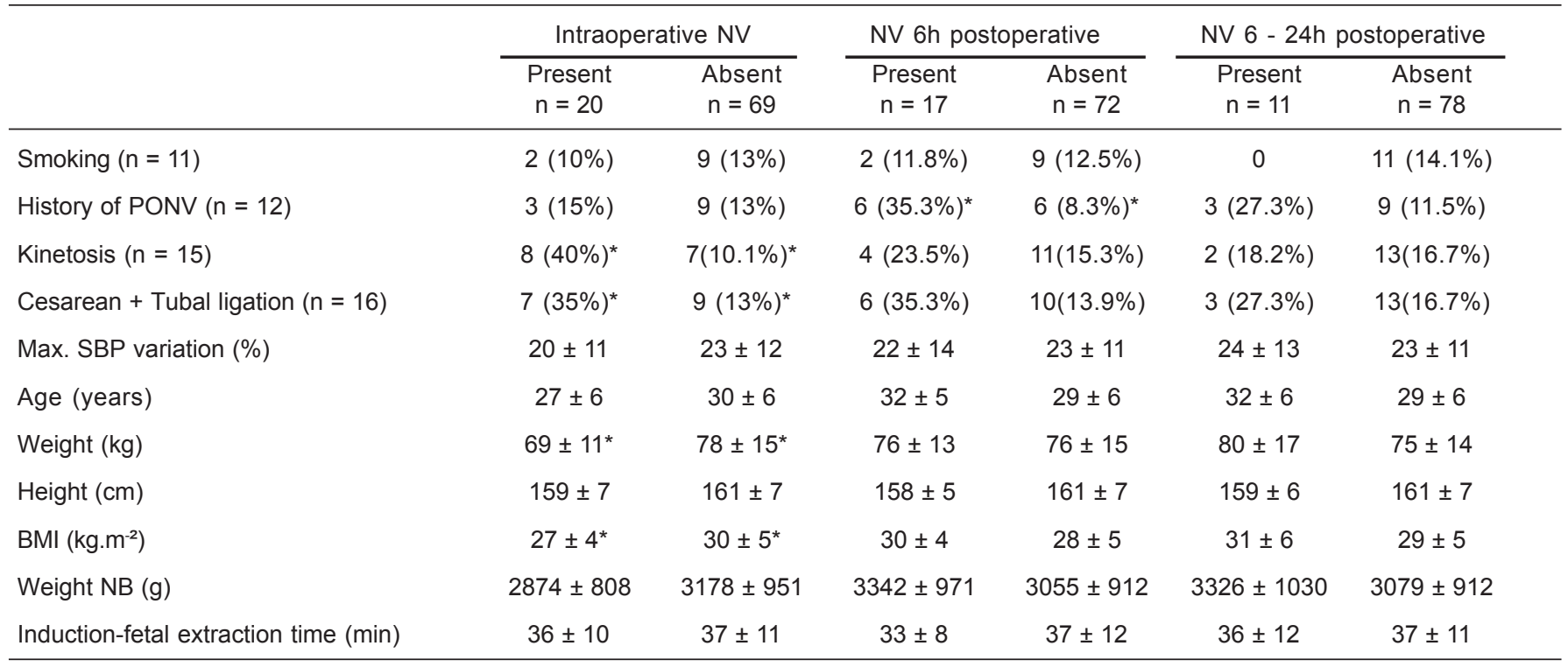

Results expressed as Mean \pm SD and frequency.

${ }^{*} p<0.05$.

Table VIII - Concordance of Intra- and Postoperative Events

\begin{tabular}{lccc}
\hline Intraoperative NV & $\begin{array}{c}\text { Present } \\
(\mathrm{n}=20)\end{array}$ & $\begin{array}{c}\text { Absent } \\
(\mathrm{n}=69)\end{array}$ & Kappa \\
\hline 6h present $(\mathrm{n}=17)$ & $7(7.9 \%)$ & $10(11.2 \%)$ & 0.217 \\
$6 \mathrm{~h}$ absent $(\mathrm{n}=72)$ & $13(14.6 \%)$ & $59(66.3 \%)$ & \\
6 - 24 h present $(\mathrm{n}=11)$ & $3(3.4 \%)$ & $8(9 \%)$ & 0.041 \\
$6-24$ h absent $(\mathrm{n}=78)$ & $17(19.1 \%)$ & $61(68.5 \%)$ & \\
\hline
\end{tabular}

A comparison among patients who had one of the events during the surgery with those who developed PONV failed to demonstrate concordance and, therefore, it was not possible to infer an association between the intra- and postoperative incidence of PONV.

\section{DISCUSSION}

Regional block is the anesthetic technique of choice for elective and emergency cesarean sections, being effective and safe. Despite marked advances in subarachnoid and epidural blocks and combined spinal-epidural block, postoperative nausea and vomiting affect most patients. They can be so uncomfortable that have a negative impact on patient satisfaction with the procedure. Several factors can be implicated in the predisposition for those events and several studies have demonstrated the importance of antiemetic prophylaxis ${ }^{8,9,22,23}$. Due to the elevated incidence of nausea and vomiting in those patients some authors defend the routine use of antiemetic prophylaxis s,7,24. $^{6}$
Pharmacological prophylaxis is not devoid of risks and it can result in an undesirable increase in surgical costs. Recently, supplemental oxygen to decrease the incidence of postoperative nausea and vomiting (PONV) has been the focus of several studies but the results have been controversial. While some patients undergoing general anesthesia benefit from it, with up to $50 \%$ reduction in the incidence of those events, the same is not seen with other patients, including high risk populations ${ }^{15,15}$. The mechanism by which supplemental oxygen reduces the incidence of PONV is uncertain, but it can be due to a reduction in the consequences of intestinal ischemia associated with handling or compression of intestinal loops, which can cause the release of intestinal mediators that trigger nausea and vomiting ${ }^{14,15}$; besides, it can also minimize the effects of medullar hypoxia, responsible for activating the vomiting center that triggers vomiting in hypotension.

The routine use of supplemental oxygen in patients undergoing elective cesarean section under regional block has been the subject of discussion in the medical literature and opinions are divided among those that defend the presence of some benefit and those that fear possible fetal complications ${ }^{13}$ caused by free radicals produced during hyperoxia. However, most studies focus only on the effects on the fetus and not on possible advantages for the parturient, which could justify the routine use of oxygen.

Women undergoing cesarean section have an increased risk of PONV than non-pregnant patients undergoing other types of surgeries ${ }^{25,26}$. This risk can be related to the physiological changes of pregnancy, but also with other factors such as uterine handling, aortocaval compression leading to 
hypotension, high doses and fast infusion of uterotonic drugs, and the use of opioids in the neuro axis. The advantages of oxygen as an antiemetic include: low potential of collateral effects or allergies, low cost, and absence of sedation and contraindication for breast feeding, allowing the mother to care for her baby ${ }^{23}$.

A clinical assay involving parturients undergoing cesarean sections under general anesthesia did not find any benefits of supplemental oxygen administered only in the immediate postoperative period in reducing the incidence of PONV ${ }^{27}$; however, this is not the anesthetic technique of choice in cesarean sections in most maternities and general hospitals all over the world ${ }^{26}$, including our hospital.

The first study designed to test the efficacy of supplemental oxygen in reducing the incidence of PONV in neuro axis block for cesarean section did not observe any benefits of administering $70 \%$ oxygen after fetal extraction when compared with $21 \%$, both on the incidence and in the severity of postoperative nausea and vomiting ${ }^{25}$. The present study was designed before the publication of that study and it has some differences in the study population: we used subarachnoid block instead of comparing subarachnoid and epidural blocks; lower dose of opioids (60 $\mu \mathrm{g}$ of morphine vs. $10 \mu \mathrm{g}$ of fentanyl $+150 \mu \mathrm{g}$ of morphine); unlike to other study, our patients did not receive any antiemetic prophylaxis. Besides, in the present study patients were randomly divided to receive oxygen or medical air immediately after anesthetic induction while in the other study patients received oxygen until fetal extraction and were divided into different groups after delivery. The population in the present study is more homogenous since it only included patients that underwent subarachnoid block avoiding possible biases such as differences in the time of installation of the sympathetic blockade, which is longer in epidural block and therefore patients are less susceptible to hypotension-induced emesis; besides, it also was a more faithful representation of most anesthesia for elective cesarean section in our service. The dose of subarachnoid opioid used was also much lower, decreasing the contribution of this factor in the pathophysiology of PONV in those women. Prophylactic metochlopramide in pregnant women is not routinely done in our service due to the potential risk of extrapyramidal symptoms that can cause discomfort and often interfere in the mother-infant relationship. The absence of prophylactic medication can be responsible for the higher incidence of perioperative nausea and vomiting compared to the other clinical study, but the results were similar.

In the present study, to avoid biases on the cause of emesis, variables associated to hypotension induced by postanesthetic sympathetic blockade and position on the surgical bed. Besides standardized hydration with Ringer's lactate and moving the uterus to the left, to reduce aortocaval compression, the blood pressure in all patients was strictly controlled and hypotension was treated with vasopressors. Additionally, data on the greater reduction in systolic blood pressure were compared to baseline levels (maximal variation of SBP) and statistically significant differences were not observed between both groups.

In the design of the present study, nasal catheter was chosen instead of the Venturi mask so the intervention would be as close to that practiced in our hospital as possible, but one should not forget the lack of precision of the inspired oxygen fraction delivered to patients. But this would be more relevant if this intervention could have been advantageous to patients. The active questioning on the symptoms studied here increases the sensitivity of the results, but it might include very mild, non-clinically significant, symptoms. For this reason, it was decided to undertake additional analysis before comparing the results, and, despite discarding mild events, statistically significant differences were not observed.

As for risk factors, smoking was not protective on PONV, but one should consider the small number of smokers in this population. It was demonstrated that a history of PONV is a risk factor for postoperative events especially in the first six hours but not for intraoperative events. Intraoperative risk factors included kinetosis and the association of tubal ligation, which increases handling of the viscera, triggering emesis. Other possible predisposing factors related to hypotension and ischemia of the vomiting center, more frequent in parturients, did not show an association in the present study.

To conclude, supplemental oxygen from induction of anesthesia until the end of the procedure did not reduce the incidence of intra- and postoperative nausea and vomiting in women undergoing cesarean section under subarachnoid block.

\section{REFERÊNCIAS - REFERENCES}

01. Abouleish E, Rawal N, Fallon K et al. - Combined intrathecal morphine and bupivacaine for Cesarean section. Anesth Analg, 1988;67:370-374.

02. Abouleish E, Rawal N, Rashad MN - The addition of $0.2 \mathrm{mg}$ subarachnoid morphine to hyperbaric bupivacaine for cesarean delivery: a prospective study of 856 cases. Reg Anesth, 1991;16:137-140.

03. Dahl JB, Jeppesen IS, Jorgensen $\mathrm{H}$ et al. - Intraoperative and postoperative analgesic efficacy and adverse effects of intrathecal opioids in patients undergoing Cesarean section with spinal anesthesia: a qualitative and quantitative systematic review of randomized, controlled trials. Anesthesiology, 1999;91:1919-1927.

04. Abboud TK, Dror A, Mosaad P et al. - Mini-dose intrathecal morphine for the relief of post-cesarean section pain: safety, efficacy, and ventilatory responses to carbon dioxide. Anesth Analg, 1988;67:137-143.

05. Swart M, Sewell J, Thomas D - Intrathecal morphine for caesarean section: an assessment of pain relief, satisfaction and side-effects. Anaesthesia, 1997;52:373-377.

06. Fuji $\mathrm{Y}$, Tanaka H, Toyooka $\mathrm{H}$ - Prevention of nausea and vomiting with granisetron, droperidol and metoclopramide during and after spinal anaesthesia for caesarean section: a randomized, doubleblind, placebo-controlled trial. Acta Anaesthesiol Scand, 1998;42:921-925. 
07. Abouleish El, Rashid S, Haque S et al. - Ondansetron versus placebo for the control of nausea and vomiting during Caesarean section under spinal anaesthesia. Anaesthesia, 1999;54:479482.

08. Chaney MA - Side effects of intrathecal and epidural opioids. Can J Anaesth, 1995;42:891-903.

09. Watcha MF, White PF - Postoperative nausea and vomiting: its etiology, treatment and prevention. Anesthesiology, 1992;77:162184.

10. Habib AS, Itchon-Ramos N, Phillips-Bute BG et al. - Transcutaneous acupoint electrical stimulation with the ReliefBand for the prevention of nausea and vomiting during and after cesarean delivery under spinal anesthesia. Anesth Analg, 2006;102:581-584.

11. Rowbotham DJ - Recent advances in the non-pharmacological management of postoperative nausea and vomiting. $\mathrm{Br} \mathrm{J}$ Anaesth, 2005;95:77-81.

12. Jordan MJ, Hill D - Women undergoing caesarean section under regional anaesthesia should routinely receive supplementary oxygen. Int J Obst Anesth 2002;11:282-288.

13. Backe SK, Lyons G - Oxygen and elective Caesarean section. Br J Anaesth, 2002;88:4-5.

14. Greif R, Laciny S, Rapf B et al. - Supplemental oxygen reduces the incidence of postoperative nausea and vomiting. Anesthesiology, 1999;91:1246-1252.

15. Goll V, Akca O, Greif R et al. - Ondansetron is no more effective than supplemental intraoperative oxygen for prevention of postoperative nausea and vomiting. Anesth Analg, 2001;92:112117.

16. Joris JL, Poth NJ, Djamadar AM et al. - Supplemental oxygen does not reduce postoperative nausea and vomiting after thyroidectomy. Br J Anaesth, 2003;91:857-861.

17. Purhonen S, Turunen M, Ruohoaho UM et al. - Supplemental oxygen does not reduce the incidence of postoperative nausea and vomiting after ambulatory gynecologic laparoscopy. Anesth Analg, 2003;96:91-96.

18. Purhonen S, Niskanen M, Wustefeld M et al. - Supplemental oxygen for prevention of nausea and vomiting after breast surgery. Br J Anaesth, 2003;91:284-287.

19. Purhonen S, Niskanen M, Wustefeld M et al. - Supplemental $80 \%$ oxygen does not attenuate post-operative nausea and vomiting after breast surgery. Acta Anaesthesiol Scand, 2006;50:26-31.

20. Donaldson AB - The effect of supplemental oxygen on postoperative nausea and vomiting in children undergoing dental work. Anaesth Intensive Care, 2005;33:744-748.

21. Treschan TA, Zimmer C, Nass $C$ et al. - Inspired oxygen fraction of 0.8 does not attenuate postoperative nausea and vomiting after strabismus surgery. Anesthesiology, 2005;103:6-10.

22. Gan TJ - Risk factors for postoperative nausea and vomiting. Anesth Analg, 2006;102:1884-1898.

23. Phillips TW Jr, Broussard DM, Sumrall WD 3rd et al. - Intraoperative oxygen administration does not reduce the incidence or severity nausea or vomiting associated with neuraxial anesthesia for cesarean delivery. Anesth Analg, 2007;105:1113-1117.
24. Nortcliffe SA, Shah J, Buggy DJ - Prevention of postoperative nausea and vomiting after spinal morphine for Caesarean section: comparison of cyclizine, dexamethasone and placebo. $\mathrm{Br} J$ Anaesth, 2003;90:665-670.

25. Borgeat A, Ekatodramis G, Schenker CA - Postoperative nausea and vomiting in regional anesthesia: a review. Anesthesiology, 2003;98:530-547.

26. Balki M, Carvalho JC - Intraoperative nausea and vomiting during cesarean section under regional anesthesia. Int J Obstet Anesth, 2005;14:230-241.

27. Ghods AA, Soleimani M, Narimani M - Effect of postoperative supplemental oxygen on nausea and vomiting after cesarean birth. J PeriAnesth Nurs, 2005;20:200-205.

\section{RESUMEN}

Pécora FST, Malbouisson LMS, Torres MLA - Oxígeno Suplementario e Incidencia de Náuseas y Vómitos Perioperatorios en el Parto Cesariano bajo Anestesia Subaracnoidea.

JUSTIFICATIVA Y OBJETIVOS: El oxígeno suplementario puede reducir la incidencia de náuseas y vómitos postoperatorios en pacientes sometidos a la anestesia general. El objetivo de este estudio, fue comprobar la eficacia del oxígeno suplementario durante la cesárea electiva bajo anestesia subaracnoidea, para reducir la incidencia de náuseas y vómitos perioperatorios.

MÉTODO: Después de la inducción de anestesia subaracnoidea estandarizada, noventa y cuatro parturientas sometidas al parto en quirófano, se distribuyeron de forma aleatoria para recibir, a través de catéter nasal tipo gafas, 4 L.min ${ }^{-1}$ de oxígeno (Grupo O), o aire comprimido (Grupo S), hasta el final del procedimiento. Se les preguntó sobre el aparecimiento de náuseas y vómitos durante la operación y en las primeras 6 y 24 horas del posparto.

RESULTADOS: Los dos grupos fueron comparables en cuanto a las variables demográficas, perioperatorias y en cuanto a los datos del recién nacido. En el Grupo O, la incidencia de náuseas durante la operación en las primeras 6 horas del postoperatorio y entre las 6 y 24 horas del postoperatorio, fue de un 35\%, 20\% y 13\%, respectivamente, mientras que en el Grupo S, fue de un 35\%, 30\% y $19 \%$, respectivamente. La incidencia de vómitos en el Grupo O fue de un $9 \%, 11 \%$ y $6 \%$ en los períodos correspondientes, y en el Grupo S, $21 \%, 7 \%$ y $7 \%$, respectivamente. Esas diferencias no fueron significativas.

CONCLUSIONES: En la población estudiada, la oxigenoterapia suplementaria desde la inducción de la anestesia hasta el término de la operación, no redujo la incidencia de náuseas o vómitos intraoperatorios y postoperatorios en mujeres sometidas al parto por cesárea bajo anestesia subaracnoidea. 